\title{
A Systematic Approach For Entrepreneurial Innovation
}

\author{
John S. Stovall, Georgia Southwestern State University, USA
}

\begin{abstract}
This paper will review some common perceptions about corporate behavior that is likely to predict a successful NPD program in established and replicated area of research. It will then test attempt to support whether those same behaviors also will predict success among entrepreneurial firms with similar strategies.
\end{abstract}

Keywords: Innovation, Opportunity Recognition, Product Development, Entrepreneurship, \& Strategic Planning

\section{INTRODUCTION}

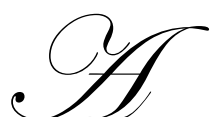

great deal of attention was spent trying to describe the "prototypical" entrepreneur by using individual personality traits. Based on these studies (e.g., Hills, Lumpkin \& Singh, 1997), it was attempted to identify these types of traits that entrepreneurs possessed that helped them be more successful than other ones. Few were actually identified and agreed upon, and Gartner (1998) wrote, "Who is an entrepreneur?" is the wrong question. He states that these personality traits and characteristics should not be studied, and instead, a behavioral approach should be used.

This shift away from trying to describe entrepreneurs using deterministic personality and cultural theory led Low \& McMillan (1988) to urge entrepreneurship researchers toward more contextual and process-oriented research. In a special issue of the journal Entrepreneurship Theory \& Practice, the editors' introduction stated that there seemed to be a growing consensus among influential scholars in the field that entrepreneurship research must become more theory driven and take advantage of progress made in other disciplines and fields (Davidsson, Low, \& Wright, 2001).

In the past few years, much research has resulted using these suggestions as a catalyst. One area that has not had much attention is whether the research findings studying the behavior of corporate managers in large organizations when developing new products can be useful to researchers studying entrepreneurs. Specifically, can the research findings that suggest certain behavior used by large corporations that have successful new product development (NPD) programs also be applied to entrepreneurial firms? This paper will review some common perceptions about corporate behavior that is likely to predict a successful NPD program in established and replicated area of research. It will then test attempt to support whether those same behaviors also will predict success among entrepreneurial firms with similar strategies.

\section{NPD RESEARCH REVIEW}

There has been much research conducted from the late 60's until today that describes a planned process used by companies who have a more successful NPD program - and even more - a more successful company than those who do not use a consistent NPD process. (e.g., Booz, Allen and Hamilton, 1968, 1982; Cooper and Klienschmidt 1996.) Booz-Allen \& Hamilton (1968) first popularized a step method they describe as the full process of evolution for a new product that is still consistent with the models currently used in research studies. The steps, along with a description of each, are:

- $\quad$ Step 1: Exploration - searching for ideas to meet company product objectives. 
- $\quad$ Step 2: Screening - weighing technological, market, and other considerations that determine whether or not the idea is of interest.

- $\quad$ Step 3: Business Analysis - analyzing and converting an idea into a concrete recommendation, and deciding to undertake a development project.

- $\quad$ Step 4: Development - turning an approved idea into a demonstrable and producible item.

- $\quad$ Step 5: Testing - conducting the product and market tests required to confirm earlier judgments and to finalize plans for production and marketing.

- $\quad$ Step 6: Commercialization - launching the new product full-scale in both production and distribution.

It was also supported by the follow-up research report by Booz-Allen and Hamilton (1982). They found that companies doubled their spending on these pre-development steps since the earlier report, and the following occurred:

- $\quad$ New product expenditures in the commercialization stage dropped from one-half to one-quarter.

- $\quad$ Spending on unsuccessful products dropped from $70 \%$ to $54 \%$.

- $\quad$ The number of ideas for new products considered to be actually developed dropped from 58 to 7 .

They, along with Cooper, felt that companies that have a consistent process are more successful than those that do not. These early studies are the blueprints for developing a more sophisticated evolution from an idea for a product to actual commercialization, and therefore they warrant current review. These findings suggest that careful planning before actual prototypes are made, what Cooper (1997) calls the "fuzzy front end," make a company's NPD program more efficient and profitable. An example of a current step model that clearly identifies the "fuzzy front end" is shown in Figure 1:

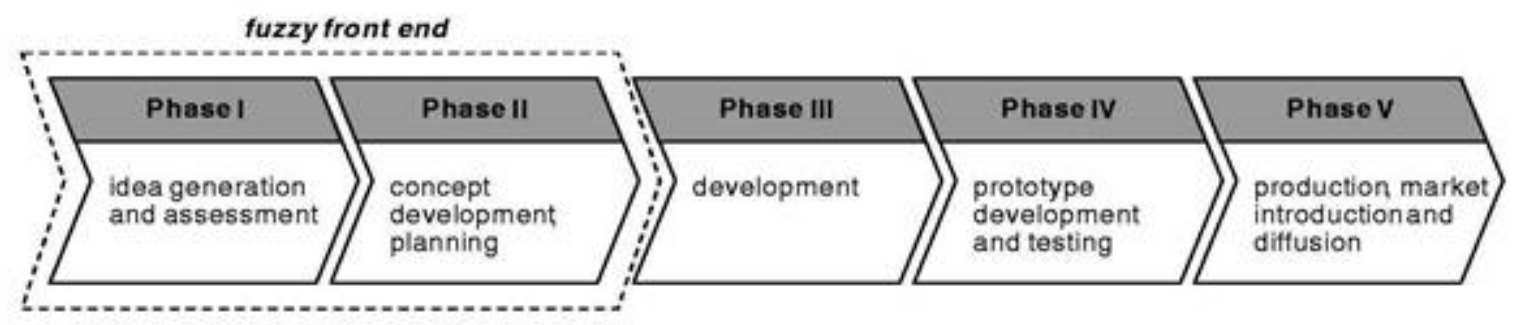

Fig. 1. The new product development process [Source: Herstatt and Verworn (2004)].

Although the NPD literature is now looking beyond the value of the early steps and instead are finding the perfect NPD team - or NPD portfolio management - the new research still supports this early diligence by following a consistent strategy of steps will pay for itself in terms of saving time and having a higher success rate of all products developed by a company. (Cooper and Edgett, 2008) Cooper and Kleinschmidt (2007) even emphasize the point, "A number of best-practice themes emerged from that 1996 (their earlier study), and they are as relevant today as then..." It is important to note that after an extensive search of research articles on the NPD, there were not any that used entrepreneurial firms in the sample of companies that participated in the studies. In fact, most studies used larger corporations that manufactured goods. It was found that that companies who used some type of systematic approach - and were consistent with the process - usually had more success in the program. (Page and Stovall, 1994)

So a question arises: What do NPD research studies say about entrepreneurial firms? Another review of the NPD research finds no instances where entrepreneurial firms are excluded from the belief that consistency in the stops of the process is a predictor of a successful overall NPD program. This leads one to believe, as Cooper and Klienschmidt (2007) announced, that it is generally accepted by the current NPD research that organizations that follow the lessons they discovered in their earlier research that a firm using a consistent approach to the process will be more successful with their NPD program - and further - are more likely to have a more successful organization as a whole. It is assumed in this study that no distinction between corporate and entrepreneurial organizations exists 
in the NPD research - and therefore - what's found to be useful in large organizations with respect to the process will also be found to be useful in entrepreneurial firms.

\section{ENTREPRENEUR BEHAVIOR DEVELOPING PRODUCTS IN OTHER RESEARCH}

There is another area of research that is popular that does study the way entrepreneurs pick new products and develop them: Opportunity Recognition $(\mathrm{OpR})$. This study is looking at business research in areas to see if the recommendations for behavior for corporate organizations can also be applied to entrepreneurial organizations. Just as the NPD research has only used larger corporations in their studies, the OpR research has concentrated solely on entrepreneurial firms. This study attempts to see if other types of research can be applied to entrepreneurs, and future studies on NPD and entrepreneurs may want to compare findings in NPD and OpR research.

There is one point needed to be made to assure the need for this type of study is important in understanding the behavior of entrepreneurs: The OpR research cannot just be a replication of the NPD research with the same findings by the researchers. They should have similarities, of course, since they are streams of research that have validity and acceptance by explaining the same type of behavior to accomplish a similar goal of producing new products in the marketplace. But, if a connection between NPD research and entrepreneurial firms can be supported in this study - and there are differences between recommendations of behavior supported in the NPD and OpR research - this will open new paths for both streams of research to pursue in future studies. This study is only interested in determining whether behavior that has been found to be successful in the NPD using surveys and findings using only corporate managers in the sample can also be applied to entrepreneurial organizations. It would be interesting to do future research on the similarities and differences between the two streams of research, but for the purposes of this particular study, it would muddy the waters by making the information considered too broad without adding much additional value in answering the questions that this paper is attempting to consider.

\section{RESEARCH QUESTION}

The objective is to discuss the similarities and/or differences between entrepreneurial and corporate firms when measuring success variables of the NPD program. Most of the findings in NPD research support a consistent plan when in the predevelopment stages when developing new products, and this study examines whether entrepreneurs can benefit in the same way.

What is the effect on the success of an entrepreneur's NPD program when comparing consistency in predevelopment activities? Do they have the same positive correlated effect as predicted by the NPD literature when comparing the same success variables?

These findings could be a major catalyst for future research in this area. If consistency in the early steps does show some positive relationship with success, future research should seek to determine ways entrepreneurs improve the quality of the processes that they perform. Large companies have certain techniques to be more successful during these steps, but not all of these relate to entrepreneurial firms. One determinant for success in a large company, for example, is the synergy between different departments and divisions within the company. Since the entrepreneur may be solo, or at least have an extremely small "management" circle, it may be determined that other steps should be taken with networks, customers, etc., to create a similar form of synergy using outside resources.

\section{METHODOLOGY} provisions:

Dun \& Bradstreet (D\&B) were given the directions to provide a mailing list that contained the following

- $\quad$ Manufacturers

- Identifiable owner/operator

- $\quad$ Minimum revenue of $\$ 1.75$ million 
According to Dillman (1991), an ideal survey manages to control for error by ensuring that all members of the population have an equal chance of being included in the sample, that sample members are randomly selected in large enough numbers to assure representability, and that everyone who is included in the sample responds. Sills and Song (2002) state that current low response rates are a problem for Internet surveys. It appears from the result of this survey that one of the main problems in designing a survey that is truly random and receives a high percentage of respondents has plagued other research surveys in the past.

Determining the effect on the returns by providing online surveys instead of paper ones would be difficult. Every respondent was given the choice to go online, receive a faxed copy by calling or emailing, or be sent one in the mail. Out of all the surveys sent, there were no requests for a hard copy. Actually, when Sills and Song (2002) describe an "internet survey," they do not accurately depict the type of methodology used for this survey.

An independent online surveyor was used to administer the survey, but the link to this site was masked behind a text block on a university website. In the space given to each respondent asking, "Did you have any problems with this survey?" there were no complaints as far as security or loss of identity using a $3^{\text {rd }}$ party web site. It would have also been very easy to use the universities resources and performed these tasks "in-house," but it was feared that if there were problems during administering the tests, the $3^{\text {rd }}$ party web site would be better qualified to handle any problems that arose because of their expertise of the system. The 61 entrepreneurs who respond to the survey is this study can be considered a convenience sample even though they are consistent with the types of sample members described above with respect to the definition of "whether they are an entrepreneur." The purpose of this paper is to begin the process of whether to consider research conducted on NPD processes can be translated, and even if this study does show support, there needs to be more rigorous studies to determine whether the NPD research can include entrepreneurial firms along with their recommendations for corporate managers.

\section{Variables Defining Success}

There have also been many questions for past research concerning the "success" a manager has with the NPD program. How the concept "success" should be operationalized? This survey asked the following statements to measure success for the product/program from past research studies, and it includes the following:

- $\quad$ Our products are more successful than our competitors

- I feel that our company develops new products more quickly than our competitors

- $\quad$ Our business is more successful than our competitors

- $\quad$ Overall, our development of new products is very successful

- $\quad$ Most of the products that we develop prototypes for are developed, enter the marketplace, and are usually successful

- $\quad$ Our firm has a higher profit margin than most of our competitors

Are all these attitudinal statements needed to measure different types of success, or do the respondents consider them all the same as in the case of the front end steps discussed above? As we can see in Table 1, each of these variables is positively correlated with other success factors. This is expected because it is rational to think that there is some connection between the success variables.

Considering the history of use in the new product development literature, and the fact that they are generally positively correlated with each other, there is a high level of comfort that each is a variable that can be employed by this study to measure success. The reason for this caution is because this study seeks to extend results that predict success when a company develops new products. One limitation of this study is that our sample contains only entrepreneurs and no corporate managers - this study actually compares the results and/or recommendations from the NPD research and compares them to the actual data received in this study. Replicating the variables used to predict the effect of the process on NPD programs run by corporate managers should be done as carefully and accurately as possible. For this reason, the consistency of variables used is very important. For example, some studies suggest that the impact of new products on sales is an important success variable (Page and Stovall, 1994), and while there may be agreement, it does fall short of consensus. The variables chosen to measure success were consistent with ones used in most of the research studies on new product development. 
Table 1: Correlations between the variables listed as success factors

\begin{tabular}{|c|c|c|c|c|c|c|}
\hline & & $\begin{array}{c}\text { Products more } \\
\text { innovative than } \\
\text { competitors }\end{array}$ & $\begin{array}{l}\text { Quicker to } \\
\text { market than } \\
\text { competitors }\end{array}$ & $\begin{array}{c}\text { Success } \\
\text { compared to } \\
\text { competitors }\end{array}$ & $\begin{array}{c}\text { Success based on } \\
\text { expectations }\end{array}$ & $\begin{array}{l}\text { Higher profits } \\
\text { than competitors }\end{array}$ \\
\hline \multirow{2}{*}{$\begin{array}{l}\text { Products more } \\
\text { innovative than } \\
\text { competitors }\end{array}$} & $\begin{array}{l}\text { Pearson Corre- } \\
\text { lation }\end{array}$ & 1 & $.449(* *)$ & $.356(* *)$ & $.328(*)$ & .163 \\
\hline & $\begin{array}{l}\text { Sig. (2-tailed) } \\
\mathrm{N}\end{array}$ & 58 & $\begin{array}{l}.000 \\
57\end{array}$ & $\begin{array}{l}.006 \\
58\end{array}$ & $\begin{array}{c}.012 \\
58\end{array}$ & $\begin{array}{l}.220 \\
58\end{array}$ \\
\hline \multirow{2}{*}{$\begin{array}{l}\text { Quicker to } \\
\text { market than } \\
\text { competitors }\end{array}$} & $\begin{array}{l}\text { Pearson } \\
\text { Correlation }\end{array}$ & $.449(* *)$ & 1 & .080 & $.334(*)$ & .018 \\
\hline & $\begin{array}{l}\text { Sig. (2-tailed) } \\
\mathrm{N}\end{array}$ & $\begin{array}{c}.000 \\
57\end{array}$ & 58 & $\begin{array}{l}.552 \\
58\end{array}$ & $\begin{array}{c}.010 \\
58\end{array}$ & $\begin{array}{c}.891 \\
58\end{array}$ \\
\hline \multirow[t]{2}{*}{$\begin{array}{l}\text { Success } \\
\text { compared to } \\
\text { competitors }\end{array}$} & $\begin{array}{l}\text { Pearson } \\
\text { Correlation }\end{array}$ & $.356(* *)$ & .080 & 1 & $.449(* *)$ & $.537(* *)$ \\
\hline & $\begin{array}{l}\text { Sig. (2-tailed) } \\
\mathrm{N}\end{array}$ & $\begin{array}{l}.006 \\
58\end{array}$ & $\begin{array}{l}.552 \\
58\end{array}$ & 59 & $\begin{array}{c}.000 \\
59\end{array}$ & $\begin{array}{l}.000 \\
59\end{array}$ \\
\hline \multirow[t]{2}{*}{$\begin{array}{l}\text { Success based on } \\
\text { expectations }\end{array}$} & $\begin{array}{l}\text { Pearson } \\
\text { Correlation }\end{array}$ & $.328(*)$ & $.334(*)$ & $.449(* *)$ & 1 & $.362(* *)$ \\
\hline & $\begin{array}{l}\text { Sig. (2-tailed) } \\
\mathrm{N}\end{array}$ & $\begin{array}{c}.012 \\
58\end{array}$ & $\begin{array}{c}.010 \\
58\end{array}$ & $\begin{array}{c}.000 \\
59\end{array}$ & 59 & $\begin{array}{l}.005 \\
59\end{array}$ \\
\hline \multirow[t]{2}{*}{$\begin{array}{l}\text { Higher profits } \\
\text { than competitors }\end{array}$} & $\begin{array}{l}\text { Pearson } \\
\text { Correlation }\end{array}$ & .163 & .018 & $.537(* *)$ & $.362(* *)$ & 1 \\
\hline & $\begin{array}{l}\text { Sig. (2-tailed) } \\
\mathrm{N}\end{array}$ & $\begin{array}{c}.220 \\
58\end{array}$ & $\begin{array}{l}.891 \\
58\end{array}$ & $\begin{array}{l}.000 \\
59\end{array}$ & $\begin{array}{l}.005 \\
59\end{array}$ & 60 \\
\hline
\end{tabular}

** Correlation is significant at the 0.01 level (2-tailed).

* Correlation is significant at the 0.05 level (2-tailed).

\section{FINDINGS}

The survey asked entrepreneurs whether they were consistent in the steps they used to develop new products - and then separated the entrepreneurial firms who did use a consistent NPD plan from those who did not. Table 2 is a t-test between these two groups and the success factors mentioned earlier. These results tend to support the NPD research that consistency in the steps of the NPD process does indeed support greater success in 5 of the 6 success variables we viewed. They were:

- $\quad$ Success rate of new products were higher

- $\quad$ The expectations (of success) of their overall NPD programs were met

- $\quad$ Their new products had more impact on the overall success of their organization

- They were able to go to market with their new products quicker than their competitors

Table 2: Consistent NPD Plan and Success

\begin{tabular}{|l|l|c|c|c|c|}
\hline & \multicolumn{1}{|c|}{ Consistent NPD Plan } & N & Mean & Significance & $\begin{array}{c}\text { Std. Error } \\
\text { Mean }\end{array}$ \\
\hline Success Rate is Good & Not Consistent & 21 & 2.86 & $.023^{*}$ & .173 \\
Success based on expectations & Consistent & 37 & 2.32 & .140 \\
& Not Consistent & 21 & 2.48 & $.084^{* *}$ & .148 \\
Success compared to competitors & Consistent & 38 & 2.13 & .120 \\
Projected Impact of NPs & Cot Consistent & 21 & 2.38 & .362 & .176 \\
Quicker to market than & Not Consistent & 38 & 2.61 & .153 \\
competitors & Consistent & 21 & 2.33 & $.033^{*}$ & .159 \\
Products more innovative than & Not Consistent & 38 & 1.92 & & .109 \\
competitors & Consistent & 21 & 2.86 & $.084^{* *}$ & .173 \\
& Not Consistent & 37 & 2.41 & & .166 \\
\hline
\end{tabular}

Note: The lower the score, the more agreement with the statement. (Strong Agree $=1$; Strong Disagree $=5$ )

** Significant at the 0.01 level (2-tailed).

* Significant at the 0.05 level (2-tailed). 
Finding support in the consistency of the NPD plan and success variables is an interesting finding when comparing entrepreneurs and corporate managers. Many early NPD studies (e.g., Booz, Allen and Hamilton, 1968; 1982) have stressed the need for consistency for companies to be more successful, efficient, and various other factors that attribute to a successful new product program. It seems likely that the effects of the early stages of the process will also effect the success variables since it has been shown that companies who become consistent there are also much more successful than their competitors (Cooper and Kleinschmidt, 1996).

\section{CONCLUSION/FUTURE RESEARCH}

This is just the first step in determining whether the process used by corporations to develop new products more successfully is the same one that entrepreneurial firms should also use. First, the NPD process used by successful entrepreneurs should be examined to see what the actual steps used by entrepreneurs is consistent with the ones suggested by the NPD literature where managers from larger corporate organizations were studied. The "fuzzy front end" was discussed prominently in this paper, and it would be interesting to see if the same types of activities before production of actual prototypes are also the ones that entrepreneurs should employ. Some think some entrepreneurs are just "savvy" and can be more intuitive when deciding upon future opportunities for their companies. (Bhave, 1995) Are some entrepreneurs just consistently more intuitive than corporate managers?

And if the NPD research can be applied to entrepreneurial firms, can the research done on entrepreneurial firms with respect to opportunity recognition be applied to corporate managers? Although the corporate NPD research makes no distinction between corporate managers and entrepreneurs, the OpR research clearly distinguishes between the two. In the introduction of this paper, Gartner's (1998) suggested that the actual behavior of an entrepreneur should be studied instead of actual personality traits or characteristics. It does stand to reason that future research in the area of NPD (or OpR) should examine the differences, or similarities, between the behaviors of successful corporate managers and entrepreneurs.

\section{AUTHOR INFORMATION}

John Stovall is an Assistant Professor of Marketing at Georgia Southwestern State University in Americus, GA. His research interests include product development, innovation, opportunity recognition, and marketing strategy.

\section{REFERENCES}

1. Bhave M, 1994. "A Process Model of Entrepreneurial Venture Creation". Journal of Business Venturing, Vol 8, pp 228-244.

2. Booz-Allen \& Hamilton. (1968). Management of New Products 4th Ed. New York.

3. Booz-Allen \& Hamilton. (1982). New product management for the 1980's. New York.

4. $\quad$ Bull, I. and G. E. Willard (1993). "Towards a theory of entrepreneurship." Journal of Business Venturing 8(3): 183-195.

5. $\quad$ Brazeal, D. V. and T. T. Herbert (1999). "The genesis of entrepreneurship." Entrepreneurship Theory and Practice 23(3): 29-45.

6. Cooper, R. G. (1997). "Fixing the fuzzy front end of the new product process: Building the business case." CMA Magazine 71(8): 21-23.

7. Cooper, Robert G. and Edgett, Scott J., (2008) Maximizing Productivity in Product Innovation, Research Technology Management, Mar/Apr, Vol. 51 Issue 2, p47-58, 12p

8. Cooper, R. G. and E. J. Kleinschmidt (1996). "Winning businesses in product development: The critical success factors." Research-Technology Management 39(4): 18-29.

9. Cooper, Robert G. C. and Klienschmidt, E. J., (2007) "Winning Businesses in Product Development: The Critical Success Factors Revisited”, Research Technology Management, 2007, Vol. 50 Issue 3, p60-61, 2p

10. Davidsson, P., M. B. Low, et al. (2001). "Editor's introduction: Low and MacMillan ten years on: Achievements and future directions for entrepreneurship research." Entrepreneurship Theory \& Practice 25(4): 5-15.

11. Gartner, W. (1988) "Who is an entrepreneur? is the wrong question". American Journal of Small Business (Spring): 11-31. 
12. Herstatt, C., Verworn, B. and Nagahira, A. (2004). Reducing project related uncertainty in the "fuzzy front end" of innovation - A comparison of German and Japanese product innovation projects. International Journal of Product Development, 1, 1: 43-65.

13. Hills, G. E., Lumpkin, G. T., \& Singh, R. P. (1997). Opportunity recognition: Perceptions and behaviors of entrepreneurs. 1997 Frontiers of Entrepreneurship Research. Wellesley, MA: Babson College.

14. Johne, F. A. and P. A. Snelson (1989). "Product Development Approaches in Established Firms." Industrial Marketing Management 18(2): 113-124.

15. Low, M. B. and I. C. MacMillan (1988). “Entrepreneurship: Past Research and Future Challenges.” Journal of Management 14(2): 139-161.

16. Page, A. L. and J. S. Stovall (1994). "Importance of the early stages in the new product development process." 1994 PDMA Proceedings: 46 - 54.

17. Verworn, Birgit, Conelius Herstatt, and Akio Nagahira (2008) "The Fuzzy Front End of Japanese New Product Development Projects: Impact on Success and Differences between Incremental and Radical Projects," R\&D Management, Vol. 38, Issue 1, pp. 1-19, January 2008. 
NOTES 